\title{
Economic Depression and the Arts in the Fifteenth-Century Low Countries*
}

\author{
JOHN H. MUNRO
}

The concept that the fine arts flourish best under conditions of economic expansion and prosperity has long been favoured by cultural historians, who have pointed in particular to the apparently obvious connection between the wealth of the Italian mercantile republics and their artistic splendour during the Renaissance of the fourteenth and fifteenth centuries. Some years ago, however, Professor Robert Lopez assailed this popular historical orthodoxy in an address to the Metropolitan Museum of Art entitled "Hard Times and Investment in Culture" (1953). ${ }^{1} \mathrm{He}$ contended that for Italy the period of genuine economic boom and greatest prosperity was not the Renaissance but rather the thirteenth century, not an era notable for its artistic achievements. The subsequent era of the Italian Renaissance was, in sharp contrast, one of economic contraction and periodically severe depressions: the product of economic dislocation from chronic widespread warfare, of famines, and worst of all, the Black Death and subsequent plagues; of disastrous depopulation over these two centuries; of general insecurity and business pessimism from such conditions; of government and guild reactions to these crises in the form of protectionist trade barriers. ${ }^{2}$ At the same time, Lopez disclaimed any purely economic interpretation of the Italian Renaissance, any direct link between these events. He did, however, offer the hypothesis that the fine arts may have received greater financial support during the Renaissance because, inter alia, humanistic culture offered the mercantile bourgeoisie commensurately more prestige, as "the highest symbol of nobility," than did mere accumulation of profits in such times of contracting investment horizons. Thus "its value rose at the very moment that the value of land fell. Its returns mounted when commercial interest rates declined." ${ }^{3}$

Over the ensuing years, Lopez's contentious views on "hard times and investment in culture" have won some converts, but by no means widespread support. ${ }^{4}$ More recently the eminent British cultural historian Peter Burke has

*An earlier and much shorter version of this paper was presented to The University College Symposium Four: "The Renaissance: Rediscovery and Exploration," on 21 January 1982, at the University of Toronto. 


\section{6 / Renaissance and Reformation}

reasserted the more traditional views on the culture and economy of this era, at least for the fifteenth-century Burgundian Low Countries, often considered to be the northern counterparts of Renaissance Italy, with such a similar combination of resplendent wealth, cultural grandeur, and active patronage of the arts by the ducal court, the Church, and the large towns. ${ }^{5}$ One may debate whether or not the Low Countries equalled or surpassed the Italians of the quattrocento in the field of painting, with such fine artists as the Van Eyck brothers, Van der Weyden, Memling, Bosch, and others. But clearly in music the Low Countries then reigned supreme: first with Dufay, then Binchois, Busnois, Ockeghem, Obrecht, Isaac, Josquin des Près, de la Rue, Compère, Gombert, Clément (Clemens non Papa); and in the sixteenth century, de Lassus, Willaert, and finally Sweelinck. In explaining all this cultural efflorescence, Burke approvingly cites the comment of the eighteenth-century Dr. Charles Burney, who was himself writing about the Low Countries in the Renaissance, that "the polite arts are children of affluence." 6

Indeed the southern Low Countries, Flanders and Brabant especially, had become by far the wealthiest, most commercialized, industrialized, urbanized, and most densely populated region in Europe north of the Alps by the late thirteenth, early fourteenth centuries. The principal if not unique foundation of that striking economic growth was this region's textile industries and trades, particularly an export trade in fine woollens that had dominated most European markets until this era and long remained unsurpassed in luxury quality. At the height of its prosperity, however, this textile industry could boast the production of not only these luxurious woollens but also a very wide range of woollen and worsted fabrics, including quite cheap sayes and serges. Burke, himself stressing the importance of this textile industry and contending that "the courtly culture of the fifteenth-century Netherlands was founded on [this] urban wealth," then quotes a motto gracing the portals of a contemporary English clothier as one that may just as aptly be applied to the Low Countries and their humanistic culture: "God be praised and ever shall; It is the sheep hath paid for all."7

Certainly there is much to be said for this viewpoint. One would not expect to find either a Jan Van Eyck or a Guillaume Dufay practising his glorious art in the rural squalor of, say, a medieval Macedonia. If man lives not by bread alone, even the most spiritually-blessed artists cannot do without it. Nevertheless I must also contend, in echoing Professor Lopez, that in the Low Countries the fifteenth century was similarly an era marked by serious economic contraction, industrial decline, and often serious depressions. That economic plight, if by no means universal, was the result of a combination of adverse factors: the general, European-wide population declines and commercial contraction, reaching their nadirs about the mid-fifteenth century; a particularly severe agrarian depression (in grain farming) in this era; warfare with France, then England, then France again; civil wars in the later part of the 
century; and other particular circumstances afflicting the region's economic mainstay, the textile industries.

Indeed in Flanders the cloth industry had reached the peak of its Golden Age as early as the 1290s; and during the fourteenth century it suffered serious disruptions from both guild conflicts that flared into destructive urban revolts (1318-19, 1323-28, 1339-49, 1359-61, 1379-86) and Flanders' involvement in both Anglo-French wars and wars with France (1297-1319, 1330s, 1380s). Such disruptions, and those from the Hundred Years' War in general, permitted foreign competitors to make serious inroads into the Flemish industry's markets, which had already become saturated and which were then reduced by the drastic European depopulations. These competitors initially included draperies in neighbouring Brabant and Holland; but the most dangerous of all - ultimately for them as well as for the Flemish - proved to be the English draperies, who were able to produce both medium- and luxuryquality woollens from the very same but much less costly wools. In fact, in this medieval era England grew by far the finest wools in Europe, wools upon which the Low Countries' draperies had become heavily dependent. From the 1330 s the English crown had sought to exploit this dependence by imposing exorbitant export duties on these wools, ranging from 30 to 65 percent of the f.o.b. export values. Furthermore, in the 1360 s, the crown created a cartel known as the Company of Merchant Staplers of Calais to control all wool exports to northern Europe and thus to ensure that this tax incidence was passed on to the foreign buyers; and monopolistic activities of the Staplers undoubtedly increased the cost of their wool purchases even further. The signal advantage that the English clothiers enjoyed, especially from the 1360 s, was their free-market and tax-free access to these same fine wools within England, while their cloth exports bore an insignificant burden, with duties of only about 2 percent. The very large English advantage will be better appreciated when one considers that in the luxury draperies of the Low Countries their tax-burdened English wools accounted for about 65-75 percent of the pre-finishing production costs. No other input was so important. ${ }^{8}$

The English cloth trade, expanding from the 1360s, soon took away many customers from the Low Countries' draperies; but the English advantages must not be exaggerated, if only because the Low Countries' luxury draperies were not finally vanquished for more than a century. Though unable to reduce their production costs sufficiently to compensate for the high cost of their wool, they still found themselves able to compete in terms of luxury quality, and were thus able to retain a goodly share of their former clientèle, especially their aristocratic customers. What permitted them to do so fairly successfully was their well-honed expertise, and - reputedly - superiority in the crucial cloth-finishing processes of fulling, shearing, and dyeing, which, as much as the fine wool itself, determined the cloth's luxury value. Forsaking cheaperline fabrics, the Flemish and Brabantine urban draperies came to concentrate 
upon and to specialize in producing a few very high quality types of luxury woollens, including their world-renowned scarlets, with very meticulous, guild-enforced quality controls. ${ }^{9}$

At the same time, some of the very conditions of economic contraction and depression in the later fourteenth and fifteenth centuries may have assisted these draperies by making quality competition as important as price competition, by giving a relative advantage to luxury production. First, the combination of much smaller markets with higher transportation costs, in view of the insecurity and trade dislocations of this era, acted to restrict production more and more to low-bulk commodities with high unit values. Second, if we may combine and adapt the "depression" theses of Professors Lopez, Herlihy, and Miskimin, one may argue that both the "inheritance effect" of drastic depopulations and some of the forces of periodic depressions tended over time to produce much greater concentrations of landed wealth amongst the nobility and the Church, but also of mercantile wealth. There is much evidence though often a conflicting, bewildering array of evidence - indicating wide extremes of great poverty and gross opulence; such extremes, however, further indicate a much more highly skewed income distribution, which would certainly have favoured luxury production (and consumption) over the cheaper line trades in textiles, such as serges and sayes. ${ }^{10}$ Third, as Miskimin and others have contended, the psychological traumas of the Black Death and successive plagues, of warfare, social upheavals, and general insecurity bred an atmosphere of hedonism amongst the upper classes, evident in increasingly ornate luxury displays. This era is certainly most famous for frequent enactments of sumptuary legislation. Perhaps for the nobility, Church, and upper bourgeoisie, costly dress and resplendent displays of opulence were not so much luxuries as necessities to defend their privileged social status in such disordered times. ${ }^{11}$ Possibly, therefore, we can now reconcile the apparent paradox of economic depression and cultural efflorescence, including luxury display - in painting, music, sculpture, and architecture - by combining the analysis of these three sets of socio-economic conditions with the earlier Lopez thesis on "hard times and investment in culture."

At this point, we can briefly note that the draperies of the Low Countries, specializing in just a few lines of high-priced luxury woollens, did succeed in withstanding English competition up to the first third of the fifteenth century, as viable if much smaller industries. But then from the 1430 s they encountered a series of reverses, then disasters that brought about a sharp, rapid, and irredeemable downfall: the extinction of all but a remnant of the urban luxury draperies in Flanders and Brabant. First, those same general market forces just analyzed also favoured the growth of the various silk industries (satins, velvets, damasks), which provided even more serious competition for the most luxurious woollens, the scarlets especially. Second, from the 1420 s the English cloth trade managed to establish a crucial base at the emerging 
Brabant Fairs of Antwerp and Bergen-op-Zoom to gain for the first time direct access to the large German and Central European markets. At the same time, English cloth merchants also gained access to the cloth-finishing crafts of Antwerp and the Dutch towns, thereby undermining the Low Countries' comparative advantage in luxury cloth production. Thirdly, from the 1430 s to the 1470s, the English crown once more sought to exploit the wool-export trade for fiscal and monetary reasons: by giving a small clique of Staplers full monopolistic control, by sharply raising wool prices, and by imposing onerous payment regulations that wrecked the vital credit system upon which these draperies had so much depended (the Calais Staple Partition and Bullion Ordinances). The draperies in Flanders and Brabant found themselves even less able to sustain these cruel blows when their principalities, under Burgundian rule, became involved in a war with England in the 1430s, cutting off their wool supply, and then in long, bitter conflicts (including mutually ruinous trade embargoes) with the German Hanseatic League, their most important customers, over the Bruges staple. Fortunately for Leiden and other Dutch draperies, Holland largely escaped these two particular conflicts; and furthermore, the Dutch sea-faring towns, after a brief and victorious piracy war with the German Wendish towns in 1438-41 that ended with the Treaty of Copenhagen, gained virtually complete free access to the large Baltic markets, enabling the Dutch draperies to take advantage of their neighbours' long conflict with the Hanseatic League. But finally, from the mid 1430s to the late 1460 s, the draperies in all three Burgundian principalities had to endure both a rigorous tight-money policy imposed by their own duke Philip the Good and the most severe commercial and agrarian phases of the late-medieval "Great Depression," its very nadir. When, in the course of the 1470 s, general European economic conditions altered to promote expansion, at least elsewhere, the damage to the Flemish and Brabantine draperies in particular had become irredeemable. Too many of their customers had been lost to the English cloth trade, and even to the Dutch.

Having myself analyzed many of these events at some length elsewhere, I refer the reader to these and other recent publications, and also to the accompanying graphs and tables. ${ }^{12}$ Graph I, offering only indirect but entirely consistent indicators of the draperies' fortunes, demonstrates the dramatic decline in the annual sales values of the drapery tax farms in Leuven, Mechelen, Ghent, and Ypres during the fifteenth century. For the last three, the decline clearly became the most precipitous from the early 1430s. Mechelen's tax farm sales, however, do suggest some recovery for that drapery alone, from the $1470 \mathrm{~s}$; but that rise may in part, at least, reflect just a rise in tax rates to compensate for the coinage debasements of that period. ${ }^{13}$ More direct and concrete evidence of industrial decay may be found in Graph II, which records the number of drapers' stalls rented each year in the Ypres cloth halls, and the physical volume of both English wool and cloth exports. 


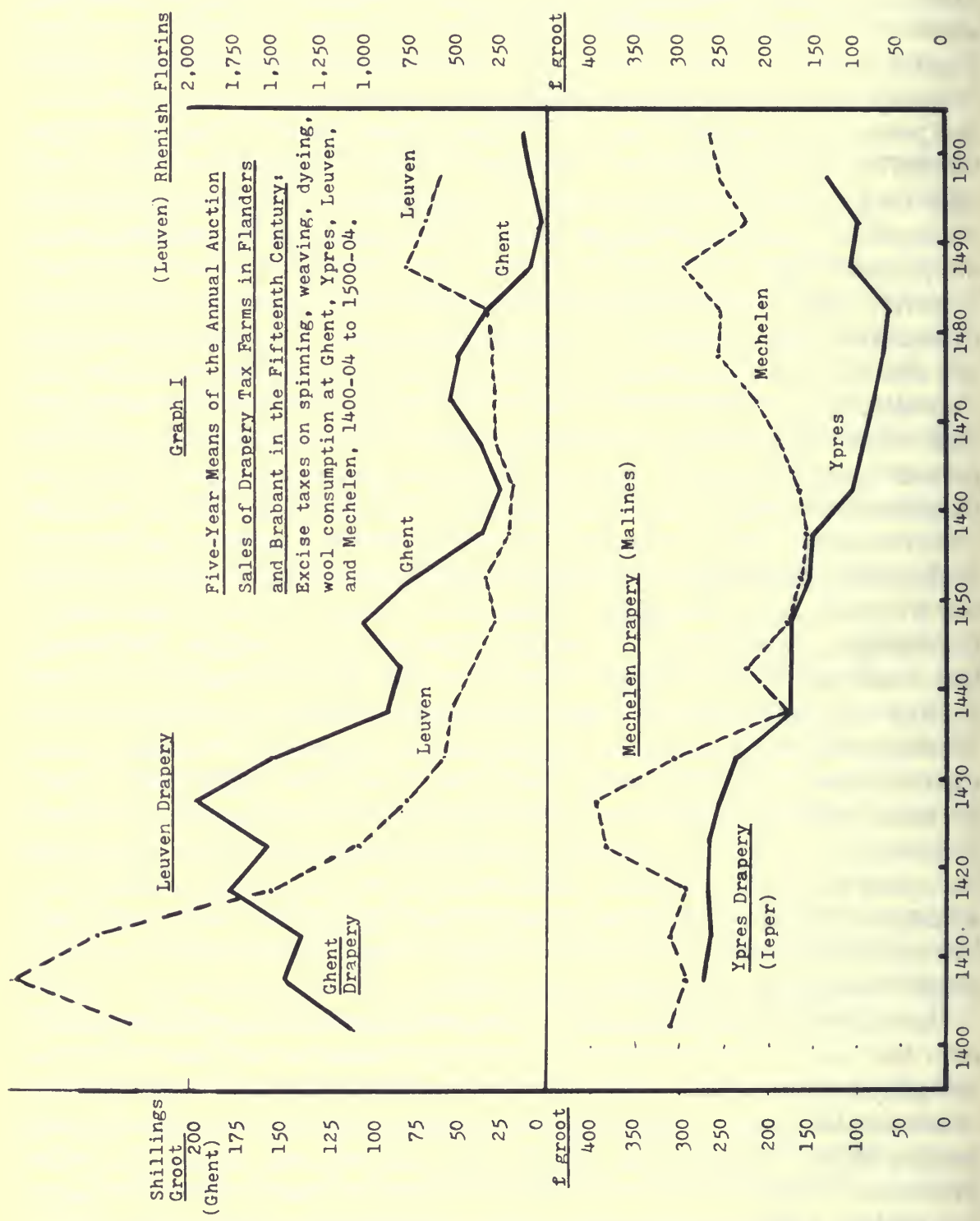

\section{SOURCES for Graphs I and II}

(a) The Leuven drapery: Stadsarchief Leuven, Stadsrekeningen, nos. 5006-124 (tax farms recorded in the annual municipal accounts).

(b) The Ghent drapery: Stadsarchief Gent, Stadsrekeningen, Reeks 400: 11-38 (tax farms recorded in the annual municipal accounts).

(c) The Mechelen draper: Stadsarchief Mechelen, Stadsrekeningen, nos. 76-190: Algemeen Rijksarchief België, Rekenkamer, registers nos. 41,219-72 (tax farms recorded in the annual municipal accounts).

(d) The Ypres drapery: Algemeen Rijksarchief België, Rekenkamer, registers nos. 38,635-722 (tax farms and hall rentals recorded in the annual municipal accounts). 

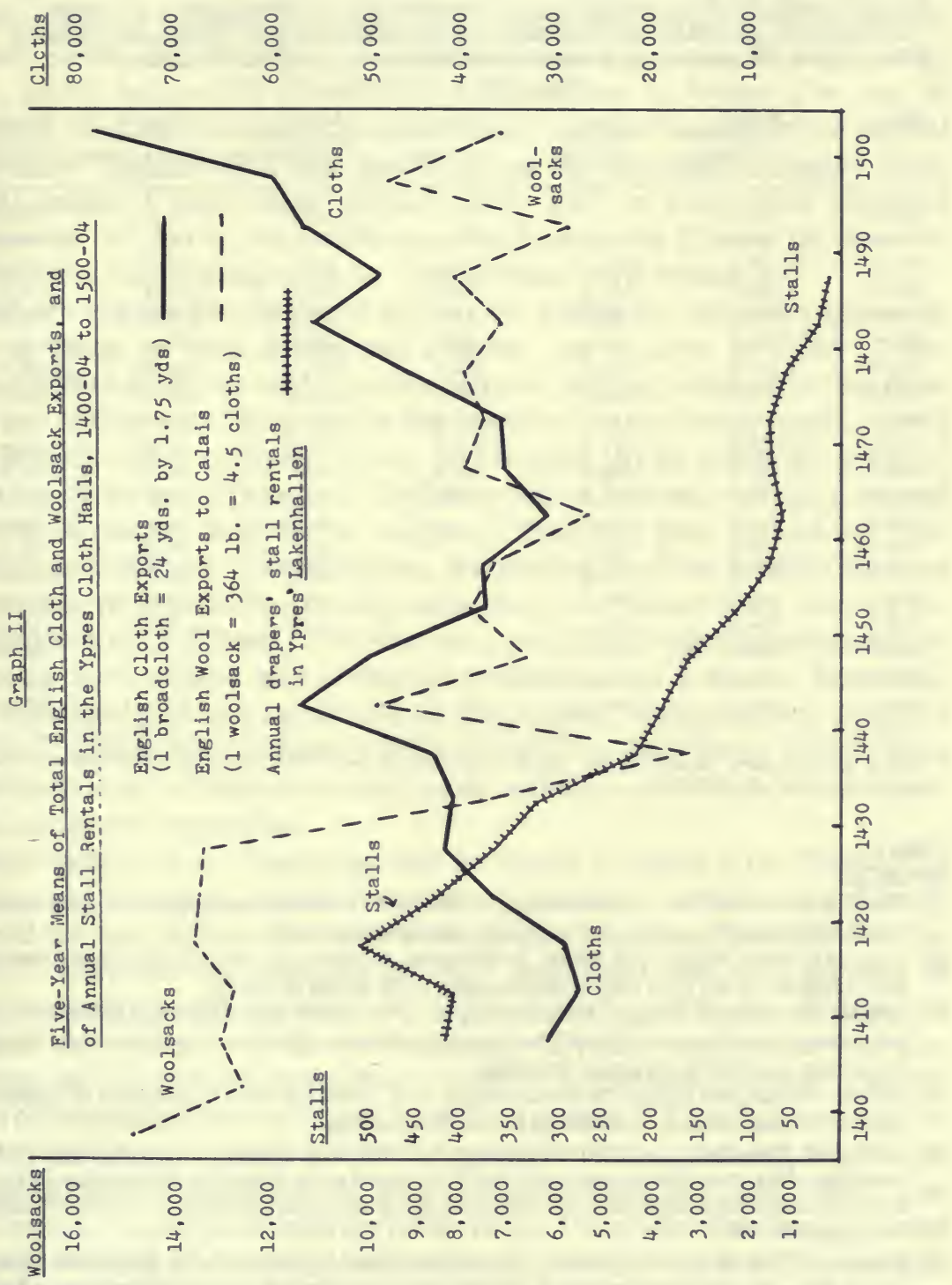

(e) English wool exports (in sacks of $364 \mathrm{lb}$.) and cloth exports (by the standard cloth of assize of 24 yards by 1.75 yards): E.M. Carus-Wilson and Olive Coleman, England's Export Trade, 1275-1547 (Oxford, 1963), pp. 55-72, 87-115, calculated from the customs accounts reports for each port, with monthly means taken to estimate annual amounts. Note: "Wool exports to Calais" total of wool exports by native or denizen merchants, who by law were required to ship their wools to the Calais Staple, where drapers from the Low Countries did obtain their English wools. English wools exported by aliens were almost entirely those Staple-exempt wools that Italian and Spanish merchants shipped directly by sea to their homelands. 
Iable 1

Price-Relatives for Fine Woollens Made from English Wools at Ghent, Ypres, and Bruges: Price-Relatives for Medium Woollens Made from non-English Wools at Leuven; and Composite Price Indices for Brabant and Flanders, Five-Year Means, from $1400-4$ to $1495-9$ *

Mean of Prices for $1400-24=100$

\begin{tabular}{|c|c|c|c|c|c|c|}
\hline Years & $\begin{array}{l}\text { Ghent 1 } \\
\text { Pine Dyed } \\
\text { Woollens } \\
100=15.930\end{array}$ & $\begin{array}{l}\text { Ypres } \\
\text { Fine Dyed } \\
\text { Woollens } \\
100= \pm 5.333\end{array}$ & $\begin{array}{l}\text { Bruges } \\
\text { Fine White } \\
\text { Woollens } \\
100=\$ 4.548\end{array}$ & $\begin{array}{l}\text { Leuven: } \\
\text { Woollens } \\
\text { (non-English) } \\
100= \pm 2.507\end{array}$ & $\begin{array}{l}\text { Brabant, } \\
\text { Composite } \\
\text { Price Index } \\
\text { Base } 100\end{array}$ & $\begin{array}{l}\text { Planders: } \\
\text { Composite } \\
\text { Price Index } \\
\text { Base } 100\end{array}$ \\
\hline $1400-4$ & 99.8 & -- & -- & 91.9 & 95.6 & 88.8 \\
\hline $1405-9$ & 99.9 & 101.6 & 99.0 & 101.5 & 100.9 & 99.3 \\
\hline $1410-4$ & 97.7 & 100.0 & 103.6 & 105.2 & 94.2 & 95.5 \\
\hline $1415-9$ & 100.1 & 103.5 & 103.8 & 104.4 & 105.8 & 109.2 \\
\hline $1420-4$ & 102.6 & 94.9 & 93.7 & 97.0 & 103.5 & 107.2 \\
\hline $1425-9$ & 102.2 & 100.5 & 99.0 & 108.8 & 114.1 & 117.8 \\
\hline $1430-4$ & 115.3 & 112.5 & 116.3 & 121.1 & 113.0 & 129.0 \\
\hline $1435-9$ & 122.8 & 121.3 & 117.3 & 108.1 & 120.9 & 138.5 \\
\hline $1440-4$ & 130.9 & -- & 162.7 & 108.0 & 103.5 & 121.3 \\
\hline $1445-9$ & 133.6 & 144.3 & 160.5 & 100.2 & 101.0 & 108.4 \\
\hline $1450-4$ & 117.2 & 142.2 & 175.9 & 88.9 & 92.5 & 101.9 \\
\hline $1455-9$ & 129.9 & 148.3 & 175.9 & 88.1 & 112.0 & 114.5 \\
\hline $1460-4$ & 134.9 & 140.8 & & 91.9 & 92.7 & 94.4 \\
\hline $1465-9$ & 136.6 & 143.9 & & 94.1 & 94.2 & 95.5 \\
\hline $1470-4$ & 145.7 & 145.8 & & 93.7 & 95.7 & 96.5 \\
\hline $1475-9$ & 149.7 & 143.8 & & 97.8 & 111.2 & 112.4 \\
\hline $1480-4$ & 174.5 & 191.1 & & 112.9 & 150.6 & 158.1 \\
\hline $1485-9$ & 251.1 & 215.4 & & & 167.6 & 164.9 \\
\hline $1490-4$ & 273.7 & 229.4 & & & 139.5 & 182.9 \\
\hline $1495-9$ & 247.3 & 251.5 & & & 111.9 & 103.0 \\
\hline
\end{tabular}

* Prices for Flanders (Ghent, Ypres, Bruges) in pounds groot Flemishi prices for Brabant (Leuven) in pounds groot of Brabant.

\section{Table 1}

\section{SOURCES}

(a) Ghent: Stadsarchief Gent, Stadsrekenigen, Reeks 400: 11-34 (annual purchases of dyed dickedinnen woollens for the civic magistrates recorded in the annual accounts).

(b) Ypres: Algemeen Rijksarchief België, Rekenkamer, registers nos. 38,635-722 (annual purchases of dyed woollens for the civic magistrates recorded in the annual accounts).

(c) Bruges: Stadsarchief Brugge, Stadsrekeningen, 1400-1499; and Algemeen Rijksarchief België, Rekenkamer, registers nos. 32,461-549 (annual purchases of the fine undyed woollens for the civic magistrates recorded in the annual accounts).

(d) Leuven: Stadsarchief Leuven, Stadsrekeningen, nos. 5006-124 (annual purchases of cheaper woollens for the lesser officials, recorded in the annual accounts).

(e) Composite Price Index for Brabant: Herman Van der Wee, "Prijzen en lonen als ontwikkelingsvariabelen: Een vergelijkend onderzoek tussen Engeland en de zuidelijke Nederlanden 1400-1700." in Album aangeboden aan Charles Verlinden ter gelegenheid van zijn dertig jaar professoraat (Ghent, 1975), pp. 413-47.

(f) Composite Price Index for Flanders: Charles Verlinden, E. Scholliers, H. Coppejans-Desmedt, J. Craeybeckx, eds. Dokumenten voor de geschiedenis van prijzen en lonen in Vlaanderen en Brabant, 4 vols. (Bruges, 1965), I and II: John H. Munro, "Mint Outputs, Money, and Prices in Late-Medieval England and the Low Countries," in Mintage, Monetary Circulation, and Exchange Rates, ed. Eddy Van Cauwenberghe and Fritz Irsigler (Leuven and Trier, forthcoming).

Again note the very sharp drop in English wool exports to the Calais Staple after 1430 (indeed, a virtual collapse in the 1430s); but also note that the decline in the number of drapers' stalls at Ypres, even steeper over the long 
run, began somewhat earlier, from the mid 1420s. Surging upwards in a directly contrary manner, English cloth exports reached their initial peak in the early 1440s; and then they, too, experienced a slump over the next twenty years, partly because of some market disruptions in France (the loss of Gascony), the Low Countries, and Germany, but more because of the general commercial depression of this period. From the late 1460s, English cloth exports resumed their steep upward climb with an even more powerful momentum, so that in the 1480 s one Dutch observer likened the flood of English cloth imports indeed to an "inundacioni maris immensi."14

Further evidence for the plight of the Low Countries' draperies and economy, in terms of both causes and effects, can be seen in Table 1. The price-relatives in the several columns show in striking contrast for the post1430 era: (a) the very sharp rise in the prices of luxury cloths manufactured from English wools at Ghent, Ypres, and Bruges; (b) the fall in the prices of cheap woollens made from non-English wools at Leuven; and (c) a general deflation in prices, in terms of weighted composite price indices for both Flanders and Brabant. This deflation, dominating the four decades between two periods of aggressive, fiscally-motivated, and inflationary coinage debasements in 1425-35 and 1474-96, was a product of both real and monetary forces: of depopulation and economic contraction; of a severe, Europeanwide scarcity of precious metals and the Burgundian "strong money" policy of this era. ${ }^{15}$ But whatever factors predominated in these price trends, such deflation certainly corresponds much more with depression than with prosperity and economic expansion.

Other indicators of depression can be found in Table 2 on "Population Decline and Poverty" in fifteenth-century Brabant, which had evidently suffered far less decline than most other parts of western Europe before the 1430 s. $^{16}$ Between the censuses of 1437 and 1480 , the total number of recorded family hearths declined by 6.7 percent; by 1496 , that decline had reached 18.8 percent of the 1437 census. If mean family size had also declined, as seems likely from other evidence on replacement rates, then the extent of depopulation would have been even greater. ${ }^{17}$ Clearly the sector that suffered the greatest decline was the agrarian, with an overall drop in the number of rural village hearths of 26.4 percent between 1437 and 1496. Those rural censuses correspond with the price trends. For while all three component groups in both the Flemish and Brabantine price indices show decline, at least until Maximilian's frenetic coinage debasements of the 1480s, the severest decline was in the grain-price index, followed by the meat and dairy products index. ${ }^{18}$ It must be noted, however, that the overall decline in the number of hearths for the "Small Towns" between 1437 and 1496 was almost as great as that for the rural hearths -25.1 percent. Perhaps that decline reflects the close ties that many small towns had with the agrarian sector; but Professor Van der Wee, in his meticulous and profound study of the Antwerp market and 
Table 2

Population Decline and Poverty in the Duchy of Brabant, $1437-1496$

Number of Pamily Hearths and Percentages of Total Hearths Without

Taxable Income ("Poor Hearths"), 1437, 1480, and 1496

Areas Covered by the

Censuses

\begin{tabular}{|c|c|c|c|c|c|}
\hline \multicolumn{2}{|c|}{1437} & \multicolumn{2}{|c|}{1480} & \multicolumn{2}{|c|}{1496} \\
\hline $\begin{array}{l}\text { Total } \\
\text { Hearths } \\
\text { in Census }\end{array}$ & $\begin{array}{l}\text { Percent- } \\
\text { age as } \\
\text { Poor } \\
\text { Hearths }\end{array}$ & $\begin{array}{l}\text { Total } \\
\text { Hearths } \\
\text { in Census }\end{array}$ & $\begin{array}{l}\text { Percent- } \\
\text { age as } \\
\text { Poor } \\
\text { Hearths }\end{array}$ & $\begin{array}{l}\text { Total } \\
\text { Hearths } \\
\text { in Census }\end{array}$ & $\begin{array}{l}\text { Percent- } \\
\text { age as } \\
\text { Poor } \\
\text { Hearths }\end{array}$ \\
\hline
\end{tabular}

A. Four Chief Towns

Brussels

Antwerp

Leuven

's Hertogenbosch

Total of Chief Towns

B. Smal1 Towns

6.376

3,440

3.579

2,883

16.278

14,159

C. Rural Villages

D. Total of Duchy

$\frac{62,301}{92,738}$

$\begin{array}{r}10.5 \\ 13.5 \\ 7.6 \\ 10.4 \\ \hline 10.5 \\ 9.2 \\ 29.7 \\ \hline 23.4\end{array}$

\begin{tabular}{|c|c|}
\hline$(7,414)$ & $(7.9)$ \\
\hline 5.450 & 10.5 \\
\hline 3.933 & 18.3 \\
\hline$(2,930)$ * & $(7.9)$ \\
\hline$(19,727)$ & $(14.8) *$ \\
\hline 12.216 & 28.1 \\
\hline 54.540 & 31.6 \\
\hline 86,483 & 27 \\
\hline
\end{tabular}

5.750

17.1

6.586

3.069

3.456

n.2.

18,861

n.2.

10,600

n.a.

45,882

n.a.

- estimated only, in the 1480 tax census

SOURCES: Joseph Cuvelier, Les dénombrements de foyers in Brabant, XIVe - XVIe siècle, 2 vols. (Brussels, 1912-13), I, cxxxv, clxxvii-viii, ccxxxiii, ccxxxvii, 432-3, 446-7, 462-77, 484-7.

Brabantine economy, has maintained that these small towns were then much more economically dependent on the traditional textile export industries whose decline has now been amply demonstrated. ${ }^{19}$

The four chief towns, however, present a different, if not totally different, picture. While both Brussels and Leuven did in fact experience some population losses between 1480 and 1496 ( 22.4 and 22.0 percent, respectively), the aggregate number of hearths in all four towns increased by 15.9 percent over the entire period $1437-1496$, thanks undoubtedly to considerable immigration from the impoverished countryside. Undoubtedly also, the reason that the big towns could receive this influx and fare better demographically is that they had much more diversified commercial and industrial economies, which, along with Antwerp's striking and special circumstances, will be discussed shortly. Leuven, furthermore, had an important and growing university, founded in 1425; Mechelen had become the judicial centre of the Netherlands; and Brussels was the centre of the resplendent Burgundian court. ${ }^{20}$

When we examine the statistics on poverty in terms of the number of non-taxable "poor hearths," the big towns again fare much better than the small towns and rural villages, perhaps reflecting again that income redistribution discussed earlier. But even so, these indicators are not quite so rosy as are the urban demographic figures. Thus the number of poor-hearths as a proportion of the total hearths in the four chief towns rises from 10.5 percent 
in 1437 to 14.8 percent in 1480 ; in Leuven, from 7.6 to 18.3 percent, more than a doubling. Poor-hearth statistics for Leuven and 's Hertogenbosch are missing from the 1496 census; but for Brussels that year, such hearths constituted 17.1 percent of the total, compared to 10.5 percent in 1437 . The highest proportion of poor hearths in 1480 is to be found, as expected, in the rural villages -31.6 percent of total hearths - but that proportion had risen by only 6.4 percent from the already high figures in the 1437 census $(29.7$ percent). By far the most dramatic increase in these poor-hearths between 1437 and 1480 is for the category of small towns: from 9.2 to 28.1 percent of total hearths, more than a tripling; in the case of the small towns in the Leuven district, chiefly drapery towns, more than a quadrupling, from 8.6 to 36.0 percent of total hearths. Regrettably, we lack comparable statistics on population and poverty for Flanders; but the record of complaints there certainly indicates a similar situation, as do available tax statistics for the adjacent county of Namur. ${ }^{21}$ According to Professor Raymond Van Uytven, taxpayers classified as "poor" in Namur rose from 49 percent of the total in 1431 to 53 percent in 1444, while their tax contributions fell from 28 percent to just 13 percent of the totals for those years.

I do not wish, however, to paint a picture of complete depression and unalloyed gloom for the Low Countries; and shafts of light could have been discerned in the discussion of the four chief towns. Thus, as the Flemish port of Bruges and the textile towns of Ypres and Ghent unquestionably declined with the decay of the traditional woollen industries, as did many other smaller towns, so Antwerp rapidly expanded by welcoming its neighbours' enemy, the English cloth trade, which along with South German silver and copper and later East Indies spices, helped to make that Brabantine port the chief entrepôt and commercial capital of northern Europe by the early sixteenth century. ${ }^{22}$ The decay of the traditional urban draperies in Flanders and Brabant also permitted, directly and indirectly, the growth of other textile industries in the Low Countries, in both towns and villages, producing counterfeit luxury woollens (nouvelles draperies) using some English but chiefly Spanish wools; worsted-type cloths (sayetteries) from coarse, non-English wools; and also linen, lace, and silk manufactures. Antwerp, Brussels, Leuven, Mechelen, and other towns also experienced a growth in various other industries, but especially luxury-oriented industries: various metal-working crafts, glove and hat, leather and fur, tapestry and embroidery, herring-processing (from Dutch fishing), cloth-finishing (especially English cloths in Antwerp and the Dutch towns), and printing. Above all, the fifteenth century witnessed the rise of the Dutch seafaring and industrial towns to supersede the Flemish and Brabantine towns in economic importance by the later sixteenth century, and then to gain world leadership in trade and finance by the seventeenth century. But clearly not for a long time did the growth of the new fully compensate for the decline of the old. Those new urban industries (which have not supplied us with any statistics like those for the draperies) could hardly have ranked in 
importance with the traditional woollen manufactures in the fifteenth century; and not really until the early sixteenth century were market conditions really propitious for the sayetteries and other cheaper-line textile producers. ${ }^{23}$ Furthermore, while in other parts of Europe both their populations and economies were recovering strongly from the 1460 s, both Flanders and Brabant (outside of Antwerp) evidently experienced the most severe phase of their own population and economic contractions in the later fifteenth century, to at least the mid-1490s. Any potential economic revival in that latter era was most certainly delayed by warfare with France (Louis XI), and then by a revolt of the Flemish towns during the misrule of the Habsburg archduke Maximilian. ${ }^{24}$

At the same time, this seventy-year period from 1430 to 1500 also marks the greatest glory of the Burgundian and then Habsburg court in the Low Countries, the very apogee of Flemish music, painting, sculpture, and architecture, civic and ecclesiastical. As Johan Huizinga has demonstrated, the stark contrasts in much of this art, contrasts of somberness and gaiety, of violence and tranquillity, of complex ornateness and simplicity, epitomize the very culture of the Renaissance Low Countries. ${ }^{25}$ We might also observe that such extreme contrasts in a way reflect those to be found in the economy and society of the fifteenth-century Low Countries. Another such reflection that well accords with Huizinga's panorama can be found in the annual records of textile purchases in the Flemish and Brabantine towns: in the later fourteenth and early to mid fifteenth centuries, a startling variety of chiefly vivid colours, with brilliant scarlets, sky-blue "celestines," orange and mixed-coloured "mellé" cloths; but in the later fifteenth century, a shift to very dark and sombre blues, greens, purples, and black, with a clear predominance of black by the end of the century. ${ }^{26}$

As Professor Lopez has already warned us, we must beware of making any strongly deterministic connections between economic depression and the fine arts; we obviously do not try to promote the latter by inducing the former. Certainly in the Low Countries the fine arts and humanistic culture all continued to flourish well into the sixteenth century: the Age of Erasmus, the Age of the Reformation, and for many the true northern Renaissance. Unquestionably also, the arts were all well represented (along with publishing) at Antwerp during its economic Golden Age from ca. 1495 to ca. $1560 .{ }^{27}$ But in my view, these were really continuations of artistic forms already established and developed in the much darker days of the fifteenth century, to me an artistically richer century in the Low Countries. ${ }^{28}$

University of Toronto

1 First published in The Renaissance: A Symposium, ed. Metropolitan Museum of Art (New York, 1953), reprinted in The Renaissance: Six Essays (New York: Harper Torchbooks, 1962), pp. 29-54. 
2 See R.S. Lopez and H.A. Miskimin, "The Economic Depression of the Renaissance," Economic History Review, 2nd ser. 14 (1962), 408-26; R.S. Lopez, H.A. Miskimin, A.L. Udovitch, "England to Egypt, 1350-1500: Long-Term Trends and Long-Distance Trade," in Studies in the Economic History of the Middle East, ed. M.A. Cook (London, 1970), pp. 93-106; R.S. Lopez, "The Trade of Medieval Europe: The South," Cambridge Economic History of Europe, II: Trade and Industry in the Middle Ages, ed. M.M. Postan and E.E. Rich (Cambridge, 1952), pp. 338-54; Harry Miskimin, The Economy of Early Renaissance Europe, 1300-1460 (Englewood Cliffs, 1969; reissued Cambridge, 1975); David Herlihy, Medieval and Renaissance Pistoia: The Social History of an Italian Town, 1200-1430 (New Haven, 1966), chapters 3-6; Benjamin Kedar, Merchants in Crisis: Genoese and Venetian Men of Affairs and the Fourteenth-Century Depression (New Haven, 1976); Jacques Heers, Gênes au XVe siècle: activité économique et problèmes sociaux (Paris, 1961). More generally, and for northern Europe, see Edouard Perroy, "A l'origine d'une économie contractée: les crises du XIVe siècle," Annales: E.S.C., 4 (1949), 167-82; Michael Postan, "Some Economic Evidence of Declining Population in the Later Middle Ages," Economic History Review, 1st ser. 9 (1939), reprinted in revised form in his Essays on Medieval Agriculture and General Problems of the Medieval Economy (Cambridge, 1973), pp. 186-213; Postan, "Medieval Agrarian Society: England," Cambridge Economic History, I: Agrarian Life of the Middle Ages, 2nd rev. edn., ed. M.M. Postan (1966), pp. 560-70; Postan, "The Trade of Medieval Europe: The North," C.E.H., II, 191-256; Jacques Heers, L'Occident aux XIVe et XVe siècles: aspects économiques et sociaux (Paris, 1963), especially pp. 86-138; Guy Fourquin, Histoire économique de l'occident médiéval (Paris, 1969), part III, pp. 295-428; Wilhelm Abel, Agricultural Fluctuations in Europe from the Thirteenth to the Twentieth Century, trans. Olive Ordish (London, 1980), chapters 1-3; John Hatcher, Plague, Population, and the English Economy, 1348-1500 (London, 1977); Wim Blockmans, "Social and Economic Effects of Plague in the Low Countries, 1349-1500," Revue belge de philologie et d' histoire, 58 (1980), 833-63; John Munro, "Bullion Flows and Monetary Contraction in Late-Medieval England and the Low Countries," in Precious Metals in the Later Medieval and Early Modern Worlds, ed. John Richards (Durham, N.C., 1983) pp. 97-158.

3 Lopez, "Hard Times," p. 48.

4 For opposing views, see comments by Prof. Hans Baron, with rejoinder by Prof. Robert Lopez in American Historical Review, 60 (1955), 385-7 and 61 (1956), 1087-9; Carlo Cipolla (with R.S. Lopez and H.A. Miskimin), "Economic Depression of the Renaissance: Rejoinder and Reply," Economic History Review, 2nd ser. 16 (1964), 519-29; A.R. Bridbury, Economic Growth: England in the Later Middle Ages (London, 1962). For supporting views, see in particular Herlihy, Pistoia, and Miskimin, Early Renaissance Europe, as in n. 2 above.

5 " "The Sheep Hath Paid For All': Peter Burke on Music and the Cloth Industry, "The Listener, 75, no 1927 (3 March 1966), 310-11.

6 Ibid., p. 311. Some of these Flemish musicians came to reside at the French, Imperial, and various Italian courts. See Gustave Reese, Music in the Renaissance (New York, 1954); Paul Henry Lang, Music in Western Civilization (New York, 1941); "The Age of Polyphony," Larousse Encyclopedia of Music, ed. Geoffrey Hindley (London, 1971), pp. 83-150; and Music and Western Man, ed. Peter Garvie (London, 1958), pp. 49-120, with contributions by Denis Stevens, Paul Henry Lang, and Gustave Reese. For town patronage of music, see Keith Polk, "Wind Bands of Medieval Flemish Cities," Brass and Woodwind Quarterly, 1 (1968), nos. 3-4 and "Municipal Wind Music in Flanders in the Late Middle Ages," Ibid., 2 (1969), nos. 1-2. See also (and listen to) Deutsche Grammaphon's Archiv series of recordings of this music.

7 Burke, p. 311.

8 See John H. Munro, "Monetary Contraction and Industrial Change in the Late-Medieval Low Countries, 1335-1500," in Coinage in the Low Countries (880-1500): Third Oxford Symposium on Coinage and Monetary History, ed. N.J. Mayhew, British Archeological Reports, International Series 54 (Oxford, 1979), pp. 110-13; Munro, "Industrial Protectionism in Medieval Flanders: Urban or National?" in The Medieval City, ed. H.A. Miskimin, D. Herlihy, and A. Udovitch (New Haven and London, 1977), pp. 229-68 (especially tables 13.1, 2, pp. 254-6, on cloth production costs); Munro, "Wool-Price Schedules and the Qualities of English Wools in the Later Middle Ages, ca. 1270-1499," Textile History, 9 (1978), 118-69; Munro, "The Medieval Scarlet and the Economics of Sartorial Splendour," in Cloth and Clothing in Medieval Europe: Essays in Memory of Professor E.M. Carus-Wilson, ed. Negley Harte and Kenneth Ponting (London, 1983), pp. 13-70 (tables 3.1, p. 32; and 3.12 , p. 52 on production costs); E.M. Carus-Wilson and Olive Coleman, England's Export 


\section{8 / Renaissance and Reformation}

Trade, 1275-1547 (Oxford, 1963), especially pp. 194-6; E.M. Carus-Wilson, "Trends in the Export of English Woollens in the Fourteenth Century," Economic History Review, 2nd ser. 3 (1950), reprinted in her Medieval Merchant Venturers (London, 1954), pp. 239-64; Eileen Power, The Wool Trade in English Medieval History (London, 1941), pp. 41-103; Terence H. Lloyd, The English Wool Trade in the Middle Ages (London, 1977), pp. 144-224; A.R. Bridbury, Medieval English Clothmaking: An Economic Survey (London, 1982), pp. 62-105; David Nicholas, Town and Countryside: Social, Economic, and Political Tensions in Fourteenth-Century Flanders (Bruges, 1971); Hans Van Werveke, Gand: Esquisse d'histoire sociale (Brussels, 1946); Van Werveke, "De economische en sociale gevolgen van de muntpolitiek der graven van Vlaanderen (1337-1433)," Annales de la Société d'Emulation de Bruges, 74 (1931), 1-15 and his "Currency Manipulation in the Middle Ages: The Case of Louis de Male, Count of Flanders," Transactions of the Royal Historical Society, 4th ser. 31 (1949), 115-27, both reprinted in his Miscellanea Mediaevalia (Ghent, 1968), pp. 243-67; Renée Doehaerd, L'expansion économique belge au moyen âge (Brussels, 1946), pp. 79-98; Raymond Van Uytven, Stadsfinanciën en stadsekonomie te Leuven van de XIIde tot het einde der XVIde eeuw (Brussels, 1961), pp. 337-91, 471-639; Van Uytven, "De omvang van de Mechelse lakenproductie vanaf de XIVde tot de XVIde eeuw," Noordgouw: cultureel tijdschrift van de provincië Antwerpen, 5 (1965), 1-22; Van Uytven, "La draperie brabançonne et malinoise du XIIe au XVIle siècle: grandeur éphémère et décadence," Produzione, commercio e consumo dei panni de lana, Seconda Settimana di Studio "Francesco Datini" a Prato, aprile 1970 (Florence, 1976), pp. 85-97; Robert-Henri Bautier, "La place de la draperie brabançonne et plus particulièrement bruxelloise dans l'industrie textile du moyen âge," Annales de la société royale d'archéologie de Bruxelles, 51 (1966), 31-63; Hektor Ammann, "Deutschland und die Tuchindustrie Nordwesteuropas im Mittelalter," Hansisches Geschichtsblätter, 72 (1954), 1-61.

9 See my publications cited above in n. 8, and also John Munro, Wool, Cloth, and Gold: The Struggle for Bullion in Anglo-Burgundian Trade, 1340-1478 (Brussels and Toronto, 1973), pp. 1-41; 181-5; Munro, "The Transformation of Flemish Cloth Production, c. 1270-1400: Responses to Changing Factor Costs and Market Demand," Centrum voor Economische Studiën, Katholieke Universiteit Leuven, Workshop on Economic History, Report no. 7103 (March, 1971); Herman Van der Wee, "Structural Changes and Specialization in the Industry of the Southern Netherlands, 1100-1600," Economic History Review, 2nd ser. 28 (1975), 205-11.

10 For Europe in general, see Lopez, "Hard Times," 34-52; Miskimin, Early Renaissance Europe, pp. 86-105, 134-44; Michel Mollat, Les pauvres au moyen âge: étude sociale (Paris, 1978), pp. 235-62; Michel Mollat and Philippe Wolff, The Popular Revolutions of the Late Middle Ages (London, 1973), pp. 91-137 (chapter 3, "Revolts Against Poverty"); Edouard Perroy, "Wage Labour in France in the Later Middle Ages" and F. Graus, "The Late Medieval Poor in Town and Countryside," both in Change in Medieval Society: Europe North of the Alps, 1050-1500, ed. Sylvia Thrupp (New York,1964), pp. 237-48, 314-25; Catherina Lis and Hugo Soly, Poverty and Capitalism in PreIndustrial Europe (Hassocks, 1979), pp. 26-96; and other sources in n. 9. For Italy, see Herlihy, Pistoia, pp. 55-210, 180-212; D. Herlihy, "Family and Property in Renaissance Florence," in The Medieval City, ed. H.A. Miskimin, D. Herlihy, A. Udovitch (New Haven, 1977), pp. 3-24; D. Herlihy, "The Distribution of Wealth in a Renaissance Community: Florence, 1427," Towns in Societies, ed. Philip Abrams and E.A. Wrigley (London, 1978), pp. 131-58; Jacques Heers, Gênes, pp. 511-43; Philip Jones, "Medieval Agrarian Society: Italy", C.E.H., I (1966), 415-18; R.S. Lopez, "Market Expansion: The Case of Genoa," Journal of Economic History, 24 (1964), 445-64 (on silk vs. wool). For England, G.A. Holmes, The Estates of the Higher Nobility in Fourteenth-Century England (Cambridge, 1966), pp. 7-41, 85-120; J.P. Cooper, "The Social Distribution of Land and Men in England, 1436-1700," Economic History Review, 2nd ser. 20 (1967), 419-40. For the Low Countries, see W.P. Blockmans and W. Prevenier, "Poverty in Flanders and Brabant from the Fourteenth to the Mid-Sixteenth Century: Sources and Problems," Acta Historiae Neerlandicae, 10 (1977), 20-57; Raymond Van Uytven, "La Flandre et le Brabant: 'terres de promission' sous les ducs de Bourgogne?"Revue du Nord, 43 (1961), 281-318; Herman Van der Wee, Growth of the Antwerp Market and the European Economy, Fourteenth to Sixteenth Centuries, 3 vols. (The Hague, 1963), II, 374-83. Van Uytven believes that during the fifteenth century there was a redistribution of income to the wealthy rentiers, merchants, industrialists, and guild-protected masters at the expense of the mass of industrial artisans and peasants; and Van der Wee similarly contends that the upper classes, especially the ledichgangers (rentiers) gained greater prosperity at the social cost "of the misery of the peasants and of the languishing workers of the old urban export industry." 
11 Miskimin, Early Renaissance Europe, pp. 132-38; Miskimin, "Monetary Movements and Market Structures: Forces for Contraction in Fourteenth and Fifteenth Century England," Journal of Economic History, 24 (1964), 470-90; Johann Huizinga, The Waning of the Middle Ages (London, 1924; Penguin edn., 1955), pp. 9-55, 130-52, 202-16, 244-344; Philip Ziegler, The Black Death (London, 1969), pp. 240-88; Johannes Nohl, The Black Death: A Chronicle of the Plague (London, 1961), pp. 96-113, 127-33; Millard Meiss, Painting in Florence and Siena After the Black Death (Princeton, 1951), cited in particular by Miskimin; Agnes Geijer, A History of Textile Art (London, 1979), pp. 141-55, 206-11; Munro, "Medieval Scarlet," pp. 13-70; Françoise Piponnier, Costume et vie sociale: la cour d'Anjou, XIVe-XVe siècle (Paris-The Hague, 1970), pp. 107-26, 163-230, 261-88. For contemporary Italian views and reactions, see Cronica di Matteo e Filippo Villani, ed. Ignazio Moutier, 6 vols. (Florence, 1825-26; reprinted Rome, 1980), I, 3-19; Giovanni Boccaccio, The Decameron, trans. J.M. Rigg (London, 1921), pp. 6-8.

12 For the following see the evidence and analyses supplied in Munro, "Monetary Contraction and Industrial Change," pp. 110-60; Munro, "Industrial Protectionism," pp. 246-68; Munro, Wool, Cloth, and Gold, pp. 65-186 (in nn. 8-9 above); and J. Munro, "Bruges and the Abortive Staple in English Cloth," Revue belge de philologie et d'histoire, 44 (1966), 1137-59; Van der Wee, "Structural Change," pp. 205-11; Van der Wee, Antwerp Market, II, 61-111, 205-11; Lloyd, Wool Trade, pp. 225-87; H.L. Gray, "English Foreign Trade from 1446 to 1482," and Eileen Power, "The Wool Trade in the Fifteenth Century," and Michael Postan, "The Economic and Political Relations of England and the Hanse from 1400 to 1475," all in Studies in English Trade in the Fifteenth Century, ed. E. Power and M. Postan (London, 1933), pp. 1-154; T.S. Jansma, "Philippe le Bon et la guerre hollandowende, 1438-1441," Revue du Nord, 42 (1960), 5-18; Philippe Dollinger, La Hanse, XIIe-XVIIe siècle (Paris, 1964), pp. 240-52, 399-404, 422-25.

13 Raymond Van Uytven believes, however, that the Mechelen drapery did enjoy a real recovery from the 1460 s, thanks in part to the town's growing role as a judicial and aristocratic court centre and to its location on the trade routes to Germany. "Omvang van de Mechelse lakenproductie," pp. 16-22 and "Draperie brabançonne," pp. 88, 94-5.

14 Dietrich Schäfer, ed. Hanserecesse, 1477-1530, 3rd ser. 9 vols. (Leipzig, 1881-1913), III, 105.

15 See Munro, "Monetary Contraction," pp. 104-10, 115-16, 140-50; Munro, "Bullion Flows and Monetary Contraction," (n. 2 above); Munro, "Mint Outputs, Money, and Prices in Late-Medieval England and the Low Countries," in Mintage, Monetary Circulation, and Exchange Rates, ed. Eddy Van Cauwenberghe and Fritz Irsigler (Leuven and Trier, forthcoming, 1984). In more general terms see Munro, "Medieval Monetary Problems: Bimetallism and Bullionism," Journal of Economic History, 43 (1983), 294-98.

16 Van der Wee, Antwerp Market, I, 545-7; II, 7-13, 31-40, 61-7; Blockmans, "Effects of Plague," pp. 833-63 (n. 2 above); Joseph Cuvelier, Les dénombrements de foyers en Brabant, XIVe-XVIe siècle, 2 vols. (Brussels, 1912-13), I, Introduction and pp. 432-87.

17 Sylvia Thrupp, "Problem of Replacement Rates in Late Medieval English Population," Economic History Review, 2nd ser. 18 (1965), 106-15; Heers, Gênes, pp. 27-8; Philippe Wolff, Commerce et marchands de Toulouse, vers 1350 - vers 1450 (Paris, 1954), pp. 102-04; Hatcher, Plague, pp. 26-30.

18 Munro, "Mint Outputs, Money, and Prices," (n. 15 above). Grain prices did not always remain low in this period, however, and shot up particularly in the 1450 s because of bad weather, trade disruptions and other "supply shocks."

19 Antwerp Market, II, 69-71; Cuvelier, Dénombrements, pp. 432-87.

20 See especially Van der Wee, Antwerp Market, II, 69-71; Van Uytven, Stadsfinanciën, pp. 471-640; Van Uytven, "Omvang van de Mechelse lakenproductie," pp. 16-22.

21 The Belgian demographer Roger Mols estimates that Ypres' population declined from ca. 20,000 in the mid to late fourteenth century to ca. 10,000 in the mid fifteenth century to ca. 5,000-6,000 by the end of the century. Introduction a la demographie historique des villes d'Europe du XIVe auXVIIIe siècles, (Louvain, 1955), II, 520-1. See also Henri Pirenne, "Les dénombrements de la population d'Ypres au XVe siècle (1412-1506)," Vierteljahrschrift für Sozial- und Wirtschaftsgeschichte, 1 (1903), reprinted in Histoire économique de l'Occident médiéval, ed. Emile Coornaert (Bruges, 1951), pp. 458-88; Munro, "Bruges," pp. 1146-47 (n. 12 above); Van Uytven, "Flandre et Brabant," pp. 281-318 (n. 10 above). 


\section{0 / Renaissance and Reformation}

22 See Munro, "Bruges," pp. 1137-59; Munro, "Industrial Protectionism," pp. 246-68; Munro, Wool, Cloth, and Gold, pp. 93-186; Van der Wee, Antwerp Market, II, 70-142; Jan Van Houtte, "La genèse du grand marché international d'Anvers à la fin du moyen âge," Revue belge de philologie et d' histoire, 91 (1940), 87-126; Van Houtte, "Anvers aux XVe et XVIe siècles," Annales: E.S.C., 16 (1961), 248-78; Van Houtte, "The Rise and Decline of the Market of Bruges," Economic History Review, 2nd ser. 19 (1966), 29-47; Etienne Sabbe, Anvers: métropole de l'occident, 1492-1566 (Brussels, 1952).

23 See especially Munro, "Monetary Contraction and Industrial Change," pp. 118-23; Emile Coornaert, Un centre industriel d' autrefois: la draperie-sayetterie d'Hondschoote, XIVe-XVIIIe siècles (Paris, 1930); Coornaert, "Draperies rurales, draperies urbaines: l'evolution de l'industrie flamande au moyen âge et au XVIe siècle," Revue belge de philologie et d' histoire, 38 (1950), 59-96; Henri Pirenne, "Une crise industrielle au XVIe siècle: la draperie urbaine et la 'nouvelle draperie' en Flandre," Bulletins de l'Academie Royale de Belgique, Classe des Lettres (1905), reprinted in Histoire économique de l'Occident médiéval, ed. Coornaert (Bruges, 1951), pp. 621-43 (to be used with care, since Pirenne confuses sayetteries with "nouvelles draperies"); Van der Wee, Antwerp Market, II, 68-83, 98-111, 119-42, 186-94; Van der Wee, "Structural change," pp. 207-15; Van Uytven, "Flandre et Brabant," pp. 283-317; J.A. Van Houtte, An Economic History of the Low Countries, 800-1800 (London, 1977), pp. 77-109, 156-210; Van Houtte, Bruges: essai d' histoire urbaine (Brussels, 1967), pp. 77-104. Sabbe, Anvers, pp. 7-19; E. Sabbe, De Belgische vlasnijverheid, I (1943; reprinted Kortijk, 1975); H. Soly and A. K. Thijs, "Nijverheid in de zuidelijk Nederlanden," Algemene geschiedenis der Nederlanden (Haarlem, 1979), VI, 37-43; Felicien Favresse, Etudes sur les métiers bruxellois au moyen âge (Brussels, 1961); Wilfrid Brulez, "Le commerce international des Pays Bas au XVIe siècle," Revue belge de philologie et d' histoire, 46 (1968), 1205-21; Marion Malowist, "L'expansion économique des Hollandais dans le bassin de la Baltique aux XIVe et XVe siècles," in his Croissance et régression en Europe, XIVe-XVIle siècles (Paris, 1972), pp. 91-138; Dollinger, La Hanse, pp. 240-52, 399-425.

24 Raymond Van Uytven, "Politiek en economie: de crisis der late XVe eeuw in de Nederlanden," Revue belge de philologie et d' histoire, 53 (1975), 1097-1149; Van Uytven, "Crisis als cessuur, 14821494," Algemene geschiedenis der Nederlanden, VI, 420-35; Van der Wee, Antwerp Market, II, 93-111; Munro, "Bruges," pp. 1137-59.

25 See $n .11$ above.

26 From the municipal treasurers' accounts of Bruges (Stadsarchief Brugge), Ghent (Stadsarchief Gent), Ypres (Algemene Rijksarchief, Rekenkamer); Leuven (Stadsarchief Leuven), Mechelen (Stadsarchief Mechelen), and Leiden (Gemeentearchief Leiden): annual purchases of woollens for the civic aldermen and other officials, variously from 1302-1550. Of these towns, Leiden (Holland) was an exception, in not shifting so predominantly to black in the late fifteenth century. See Munro, "Scarlet," pp. 13-70 and Piponnier, Costume et vie sociale, pp. 188-94, 206-25.

27 See nn. 6 and 22-23 above, especially Sabbe, Anvers, pp. 20-90, 91-107 (“L'art anversois”), with bibliography, p. 119. See also Raymond Van Uytven, "What is New Socially and Economically in the Sixteenth-Century Netherlands?" Acta Historiae Neerlandicae, 7 (1974), 18-53; Van der Wee, Antwerp Market, II, 130-243; Renée Doehaerd, Etudes anversoises: documents sur le commerce international à Anvers, 1488-1514, 3 vols. (Paris, 1963).

28 I must admit to personal bias on this issue, since it was the discovery of this fifteenth-century music in the CBC series Music and Western Man (broadcast in 1955-6, published in 1958, as in n. 6) that converted me at university from a business to an academic career, specializing in the economic history of the Low Countries. 